\title{
The Association Between Green Tea Consumption with Cardiovascular Related Mortality: A Meta-Analysis
}

\author{
Isnani Nurhayati'), Anas Rahmad Hidayat²), \\ Tri Yuniarti'), Harpeni Siswati Budi²) \\ ${ }^{1)}$ School of Health Sciences Mamba'ul 'Ulum, Surakarta, Indonesia \\ 2)Health Polytechnic of Permata Indonesia, Jogjakarta
}

\section{ABSTRACT}

Background: Tea (green or black) are among the most widely consumed beverages in adults worldwide. Recently, numerous studies claimed that green tea intake have been associated with reduced mortality, including cardiovascular disease related mortality. This study was aimed to investigate the association between green tea consumption with cardiovascular related mortality. Subjects and Method: This was a systematic review and meta-analysis study used articles which published in 2000 to 2021 from online databases, such as PubMed, ResearchGate, Science Direct, Google Scholar, and EBSCO. The dependent variable was cardiovascular related mortality. The independent variables was green tea consumption. The data was analyzed by RevMan 5.3 software. This study used the eligibility criteria with the PICO model, populations: COVID-19 general adults, intervention: $>1$ cups green tea consumption. comparison: null or $<1$ cup green tea consumption, outcome: cardiovascular related mortality. The inclusion criteria were an article describing the effect or relationship of green tea consumption with cardiovascular related mortality, original research, and study of cohort contain effect size of hazard ratio and match with the intervention design. The keywords used to search the database were "green tea" AND "cardiovascular" AND "mortality" OR "Death" AND cohort.

Results: A subgroup analysis was conducted from 4 articles which stated that cardiovascular related mortality is lower on adults who frequently consumed green tea more than one cups per day compare to adults who drank less than one cup per day $(\mathrm{HR}=0.88 ; 95 \% \mathrm{CI}=0.85$ to $0.92 ; \mathrm{p}=$ $<0.001)$ and it is statistically significant.

Conclusion: The consumption of green tea more than one cups per day may reduce the risk of cardiovascular related mortality.

Keywords: green tea, mortality, cardiovascular.

\section{Correspondence:}

Isnani Nurhayati. School of Health Sciences Mamba'ul 'Ulum, Jl. Ring Road Utara, Tawangsari, Mojosongo, Jebres, Surakarta, Central Java. Email: isnanimu@yahoo.com. Mobile: +62 812-26026662.

Cite this as:

Nurhayati I, Hidayat AR, Yuniarti T, Budi HS (2021). The Association Between Green Tea Consumption with Cardiovascular Related Mortality: A Meta-Analysis. J Epidemiol Public Health. 06(04): 472-481. https://doi.org/10.26911/jepublichealth.2021.06.04.08.

cc (7) (-) (-) miology and Public Health is licensed under a Creative Commons

Attribution-NonCommercial-ShareAlike 4.o International License.

\section{BACKGROUND}

Cardiovascular disease was one of the most common leading causes of mortality worldwide. According to the World Health Organization (2014), cardiovascular disease accounted for $17 \cdot 5$ million deaths world- wide in 2012, representing $31 \%$ of all global deaths, respectively. Over the past few decades, dietary factors were postulated to play an important role in the prevention of various degenerative diseases (Chen et al., 2008; Tangney and Rasmussen, 2013). 
Green tea is consumed primarily in eastern countries like China, Japan, and a few countries in North Africa and the Middle East, while black tea is mostly consumed by western countries (Katiyar and Elmets, 2001). The bioactive phytonutrients responsible for the pharmacological activities of green tea are believed to include tea polyphenols, known as catechins. The major catechins in green tea include epicatechin, epigallocatechin, epicatechin gallate, and epigallocatechin gallate (Khan and Mukhtar, 2018). Green tea is rich in catechin polyphenols in which catechins (epicatechin, epigallocatechin, epicatechin gallate, epigallocatechin gallate) and flavanols represent $80-90 \%$ and $<10 \%$ of total flavonoids, respectively (Balentine et al., 1997). Regular green tea consumption may reduce the risk of cardiovascular disease and cancer, possibly due to its tea polyphenols (Liu et al., 2016).

It has been proved that an increased level of plasma cholesterol is a major risk factor for cardiovascular disease. Tea and its polyphenols could lower plasma cholesterol levels by increasing the expression of LDL and reducing the oxidisation of LDL. It has also been suggested that tea can inhibit the process of atherosclerosis by removing reactive oxygen species, inducing hypolipaemia and decreasing antifibrinolysis (Brown and Goldstein, 1998; Kuhn et al., 2004; Vinson et al., 2004).

Numerous studies have been performed regarding the potential beneficial effects of green tea on cardiovascular disease risk profile such as reducing body fat, serum LDL-cholesterol, total cholesterol, triglycerides and blood pressure (Erba et al., 2005; Imai and Nakachi, 1995; Maron et al., 2003; Nagao et al., 2007; Nagaya et al., 2004; Serafini et al.,1996; Tong et al., 2014; Yang et al., 2004). Recent epidemiological studies have explored the associations between tea consumption and a wide range of conditions (including diverse cancers, cardiovascular outcomes, metabolic disorders, skeletal diseases, cognitive disorders, and other outcomes such as maternal outcomes and rheumatoid arthritis) (Yi et al., 2019).

Despite the possible fact of protective role of green tea consumption in risk of specific chronic disease mortality in humans has been suggested in epidemiological studies, these findings remain controversial, there have been inconsistent conclusions as to whether tea consumption is beneficial or harmful to health, and the health effects of tea vary among different outcomes.

Therefore, the purpose of this study was to investigate the association between green tea consumption with all cause mortality, cardiovascular related mortality and cancer related mortality.

\section{SUBJECTS AND METHOD}

\section{Study Design}

This study was a systematic review of article published from 2000 to 2021 conducted from January 1-31, 2021. We search articles using the online databases of PubMed, ResearchGate, Science Direct, Google Scholar and EBSCO. The articles used in this review are articles published from 2000 to 2021. In the process of searching for articles, we used the keywords "green tea" AND "cardiovascular" AND "mortality" OR "death" AND cohort.

\section{Inclusion and Exclusion Criteria}

The inclusion criteria of this study were: 1) an article describing the effect or relationship of green tea consumption with cardiovascular related mortality; 2) original research papers; 3) study of cohort contain effect size of hazard ratio and match with the intervention design. 
The exclusion criteria for this study were: 1) articles in languages other than English and Indonesian; 2) review papers.

\section{Study Variables}

The dependent variable was cardiovascular related mortality. The independent variables was green tea consumption.

\section{Operational Definition of Variables}

Green tea consumption defined by the habit or the amount of cup of green tea consumption within a day.

\section{Cardiovascular related mortality was} assessed by the amount of dead by cardiovascular disease.

\section{Research Instrument}

We got total 245 of articles from searching through online databases (PubMed, ResearchGate, Science Direct, Google Scholar and EBSCO). The process of searching and filtering articles using a Prism diagram (figure 1). Articles included in this study must meet the inclusion criteria and have been reviewed using a critical appraisal in accordance with the research design of the article used. A total of 4 articles were included for this study.

\section{RESULTS}

\section{Characteristic of articles included}

The included studies' characteristics can be found in Table 1. The study's characteristics consisted of the author and years of publication, study design, country, age and sample size, median or follow up year, type of intevention, type of control, outcome. All studies were carried out in Japan. Overall, 303,712 respondents were included in this study from all articles. Age of respondents of studies ranged from 40 to 84 . The duration of follow-up ranged from 6 to 21 years.

This study only included multivariate hazard ratio adjusted with other factors such as Age, education, income, smoking status, alcohol intake, physical activity, sex, job status, energy intake, body mass index , dayli consumption of miso, meat, fish, fruits, vegetables, black tea, oolong tea, and cofee, history of hypertension, gastritis. All respondents were without history of stroke, diabetes, coronary heart disease, or cancer at baseline.

\section{Cardiovascular Disease Related Mortality and Green Tea Consumption}

This study stated that cardiovascular disease related mortality is 0.85 lower mong people who drank green tea more than 1 cups per day, as compared with those who drank green tea less than 1 cup per day $(\mathrm{HR}=0.88 ; 95 \% \mathrm{CI}=0.85$ to $0.92 ; \mathrm{p}=$ $<0.001)$ and it is statistically significant (figure 2).

This statement also showed on the result of each of all 7 subgroups analysis divided by gender and the amount of cups consumed by the subject, which include all participants 1-2 cups per day, men only 1-2 cups per day, women only 1-2 cups per day, men only 3-4 cups per day, women only 3-4 cups per day, men only $>5$ cups per day, and women only $>5$ cups per day (figure 2). However not all these results were statistically significant, only 3 categories showed statistic significancy, which were women only 3-4 cups per day $(\mathrm{HR}=0.86$; CI $95 \%=0.78$ to $0.94 ; \mathrm{p}=0.002$ ), men only $>5$ cups per day $(\mathrm{HR}=0.87$; $\mathrm{CI} 95 \%=0.78$ to $0.96 ; \mathrm{p}=0.008)$, and women only $>5$ cups per day $(\mathrm{HR}=0.73$; CI $95 \%=0.65$ to $0.82 ; \mathrm{p}=<0.001)$. This result also indicated that the more cups of green tea adults consumed the lower chance to death because cardiovascular disease. Although, there is some interesting finding between the result of subgroup women only who consumed 3-4 cups per day with man only who consumed 3-4 cups per day, despite the same of amount of cups of green tea 
consumed, the pooled hazard ratio and statistic significancy was quite different.

We used the result based on fixed effect because total heterogenity showed value less than $50 \%(I 2=42 \% ; p=0.002)$. Based on the subgroup funnel plot analysis, there is no publication bias in all subgroup, except for subgroup women 5 cups perday. It has publication bias because the location and number of circles representing each article between the left and right plot were asymmetrical (figure 3). This also could affect the result of the forest plot, which meant that the result of analysis in subgroup men could be underestimate because all studies more inclined to below of the left side of the plot.

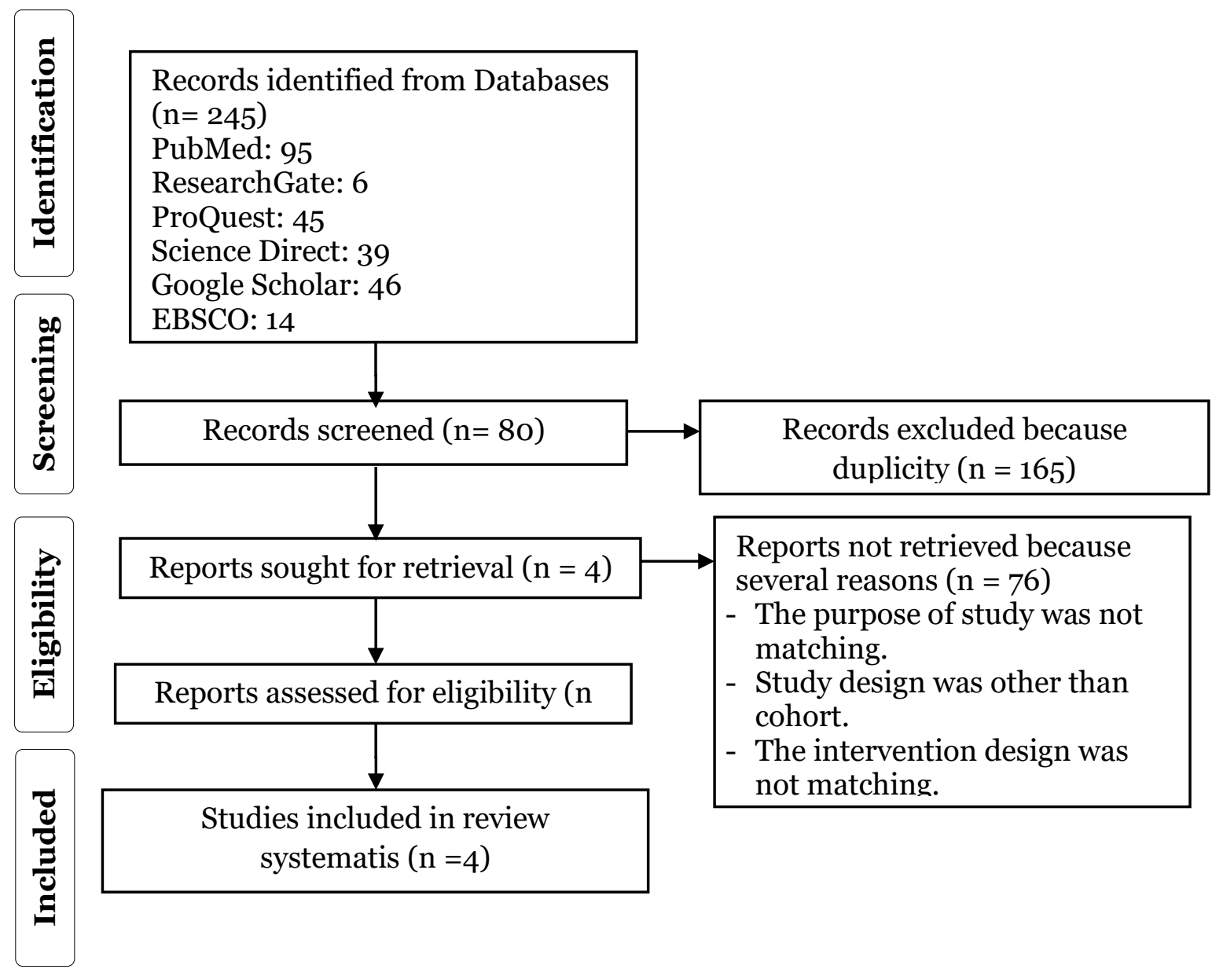

Figure 1. PRISMA Diagram 
Nurhayati et al./ Green Tea Consumption with Cardiovascular Related Mortality

Table 1. Characteristic of Articles Included

\begin{tabular}{|c|c|c|c|c|c|c|c|c|}
\hline No & $\begin{array}{l}\text { Author } \\
\text { (year) }\end{array}$ & $\begin{array}{c}\text { Study } \\
\text { design }\end{array}$ & Country & Subject (age) & $\begin{array}{c}\text { Follow up } \\
\text { year }\end{array}$ & Intervention & Control & Outcome (Effect Size/ CI 95\%) \\
\hline 1. & $\begin{array}{l}\text { Kuriyama et } \\
\text { al. (2006) }\end{array}$ & Cohort & Japan & $\begin{array}{c}40,530 \\
(40-79 \text { years) }\end{array}$ & $1995-2001$ & $\begin{array}{l}\text { 1-2 cups per day } \\
\text { 3-4 cups per day } \\
>5 \text { cups per day }\end{array}$ & $<1$ cup per day & $\begin{array}{l}\text { All participants } \\
\text { CVD mortality 0.96 (0.87-1.05) } \\
\text { 0.90 (0.82-0.98) } \\
\text { o.84 (0.77-0.92) } \\
\text { Men } \\
\text { CVD mortality 0.93 (0.83-1.05) } \\
\text { o.95 (0.85-1.06) } \\
\text { o.88 (0.79-0.98) } \\
\text { Women } \\
\text { CVD mortality 0.98 (0.84-1.15) } \\
\text { o.82 (0.70-0.95) } \\
0.77 \text { (0.67-0.89) }\end{array}$ \\
\hline 2. & $\begin{array}{l}\text { Mineharu et } \\
\text { al. (2009) }\end{array}$ & Cohort & Japan & $\begin{array}{c}76.979 \\
\text { (40-79 years) }\end{array}$ & 1995-2003 & $\begin{array}{l}\text { 1-2 cups per day } \\
\text { 3-4 cups per day } \\
>5 \text { cups per day }\end{array}$ & $\begin{array}{l}<1 \text { cup per } \\
\text { day }\end{array}$ & $\begin{array}{l}\text { Men } \\
\text { CVD mortality } 1.31(0.80-2.14) \\
0.88(0.41-1.87) \\
\text { o.74 (0.30-1.78) } \\
\text { Women } \\
\text { CVD mortality 0.77 (0.48-1.26) } \\
\text { o.81 (0.56-1.18) } \\
0.62(0.40-0.98)\end{array}$ \\
\hline 3. & $\begin{array}{l}\text { Saito et al. } \\
(2015)\end{array}$ & Cohort & Japan & $\begin{array}{c}90,914 \\
\text { (40-69 years) }\end{array}$ & $\begin{array}{c}1990 / 1994^{-} \\
2011\end{array}$ & $\begin{array}{l}\text { 1-2 cups per day } \\
3-4 \text { cups per day } \\
>5 \text { cups per day }\end{array}$ & $<1$ cup per day & $\begin{array}{l}\text { Men } \\
\text { CVD mortality 0.70 (0.43-1.13) } \\
\text { o.50 (0.3-0.82) } \\
\text { o.70 (0.43-1.16) } \\
\text { Women } \\
\text { CVD mortality 0.86 (o.61-1.22) } \\
\text { o.75 (o.57-1.00) } \\
\text { o.61 (0.45-0.82) }\end{array}$ \\
\hline 4. & $\begin{array}{l}\text { Suzuki et al. } \\
(2009)\end{array}$ & Cohort & Japan & $\begin{array}{c}14,001 \\
(65-84 \text { years })\end{array}$ & 2000-2006 & 1-2 cups per day & $<1$ cup per day & $\begin{array}{l}\text { All participants } \\
\text { CVD mortality } 0.61(0.39-0.98) \\
\text { Men } \\
\text { CVD mortality } 0.79(0.42-1.50) \\
\text { Women } \\
\text { CVD mortality } 0.46(0.23-0.91)\end{array}$ \\
\hline
\end{tabular}


Nurhayati et al./ Green Tea Consumption with Cardiovascular Related Mortality

Hazard Ratio

Hazard Ratio

Study or Subgroup log[Hazard Ratio]

SE Weight IV, Fixed, $95 \% \mathrm{Cl}$

IV, Fixed, $95 \% \mathrm{Cl}$

$\begin{array}{lrrrr}\text { 1.1.1 All Participants 1-2 cups per day } & & & \\ \text { Kuriyama (2006) } & -0.0408 & 0.0502 & 17.0 \% & 0.96[0.87,1.06] \\ \text { Suzuki (2009) } & -0.4943 & 0.2282 & 0.8 \% & 0.61[0.39,0.95] \\ \text { Subta } & & & 17.9 \% & 0.94[0.85,1.03]\end{array}$

$-0.4943 \quad 0.2282-0.8 \% \quad 0.61[0.39,0.95]$

Subtotal $(95 \% \mathrm{Cl})$

$17.9 \% 0.94[0.85,1.03]$

Heterogeneity: $\mathrm{Chi}^{2}=3.77, \mathrm{df}=1(\mathrm{P}=0.05) ; \mathrm{I}^{2}=73 \%$

Test for overall effect: $Z=1.26(P=0.21)$

1.1.2 Men $1-2$ cups per day

Kuriyama (2006)

Mineharu (2009)

Saito (2015)

Suzuki (2009)

Subtotal $(95 \% \mathrm{Cl})$

$\begin{array}{rrrr}-0.0726 & 0.058 & 12.8 \% & 0.93[0.83,1.04] \\ 0.27 & 0.2516 & 0.7 \% & 1.31[0.80,2.14] \\ -0.3567 & 0.2486 & 0.7 \% & 0.70[0.43,1.14] \\ -0.2357 & 0.3223 & 0.4 \% & 0.79[0.42,1.49]\end{array}$

Heterogeneity: $\mathrm{Chi}^{2}=3.41, \mathrm{df}=3(\mathrm{P}=0.33) ; \mathrm{I}^{2}=12 \%$

Test for overall effect: $Z=1.38(P=0.17)$

1.1.3 Women $1-2$ cups per day

Kuriyama (2006)

Mineharu (2009)

$-0.0202 \quad 0.0786$

$7.0 \% \quad 0.98[0.84,1.14]$

Saito (2015)

$\begin{array}{ll}-0.2614 & 0.2411\end{array}$

$\begin{array}{ll}-0.1508 \quad 0.1752 \\ -0.7765 & 0.3537\end{array}$

$0.7 \% \quad 0.77[0.48,1.24]$

Suzuki (2009)

$-0.7765 \quad 0.3537$

$1.4 \% \quad 0.86[0.61,1.21]$

Subtotal $(95 \% \mathrm{Cl})$

$\begin{array}{ll}0.3 \% & 0.46[0.23,0.92]\end{array}$

Heterogeneity: $\mathrm{Chi}^{2}=5.18, \mathrm{df}=3(\mathrm{P}=0.16) ; \mathrm{I}^{2}=42 \%$

Test for overall effect: $Z=1.27(P=0.20)$

1.1.4 Men 3-4 cups per day

Kuriyama (2006)

Mineharu (2009)

Saito (2015)

Subtotal $(95 \% \mathrm{Cl})$

$\begin{array}{llll}-0.1278 & 0.3897 & 0.3 \% & 0.88[0.41,1.89]\end{array}$

$\begin{array}{llll}-0.6931 & 0.2606 & 0.6 \% & 0.50[0.30,0.83]\end{array}$

Heterogeneity: $\mathrm{Chi}^{2}=5.81, \mathrm{df}=2(\mathrm{P}=0.05) ; \mathrm{I}^{2}=66 \%$

Test for overall effect: $Z=1.48(P=0.14)$

1.1.5 Women 3-4 cups per day

Kuriyama (2006)

Mineharu (2009)

$\begin{array}{ll}-0.1278 & 0.055\end{array}$

$14.2 \% \quad 0.88[0.79,0.98]$

$-0.2107 \quad 0.1883$

$1.2 \% \quad 0.81[0.56,1.17]$

Saito (2015)

$-0.2877 \quad 0.14$

$0.75[0.57,0.99]$

Subtotal $(95 \% \mathrm{Cl})$

$17.6 \% 0.86[0.78,0.94]$

Heterogeneity: $\mathrm{Chi}^{2}=1.23, \mathrm{df}=2(\mathrm{P}=0.54) ; \mathrm{I}^{\mathbf{2}}=0 \%$

Test for overall effect: $Z=3.11(P=0.002)$

1.1.6 Men $>5$ cups per day

Kuriyama (2006)

Mineharu (2009)

Saito (2015)

Subtotal $(95 \% \mathrm{Cl})$

$\begin{array}{llll}-0.1278 & 0.055 & 14.2 \% & 0.88 \\ {[0.79,0.98]}\end{array}$

$\begin{array}{llll}-0.3011 & 0.4607 & 0.2 \% & 0.74[0.30,1.83]\end{array}$

$\left.\begin{array}{llll}-0.3567 & 0.2486 & 0.7 \% & 0.70[0.43,1.14\end{array}\right]$

Heterogeneity: $\mathrm{Ch}^{2}=0.93, \mathrm{df}=2(\mathrm{P}=0.63) ; \mathrm{I}^{2}=0 \%$

Test for overall effect: $Z=2.64(P=0.008)$

1.1.7 Women $>5$ cups per day

Kuriyama (2006)

Mineharu (2009)

$-0.2614 \quad 0.071$

$8.5 \% \quad 0.77[0.67,0.88]$

$\begin{array}{ll}-0.478 \quad 0.2236 \\ -0.4943 & 0.1552\end{array}$

$0.9 \% \quad 0.62[0.40,0.96]$

Saito (2015)

$-0.4943 \quad 0.1552$

$1.8 \% 0.61[0.45,0.83]$

Subtotal $(95 \% \mathrm{Cl})$

$11.2 \% 0.73[0.65,0.82]$

Heterogeneity: $\mathrm{Chi}^{2}=2.44, \mathrm{df}=2(\mathrm{P}=0.30) ; \mathrm{I}^{2}=18 \%$

Test for overall effect: $Z=5.08(P<0.00001)$

Total $(95 \% \mathrm{Cl})$

$100.0 \% \quad 0.88[0.85,0.92]$

Heterogeneity: $\mathrm{Chi}^{2}=36.08, \mathrm{df}=21(\mathrm{P}=0.02) ; \mathrm{I}^{2}=42 \%$

Test for overall effect: $Z=6.03(P<0.00001)$

Test for subqroup differences: $\mathrm{Chi}^{2}=13.31, \mathrm{df}=6(\mathrm{P}=0.04)_{\mathrm{l}} \mathrm{I}^{2}=54.9 \%$

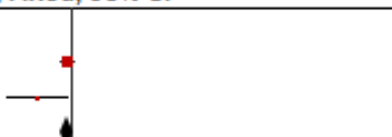




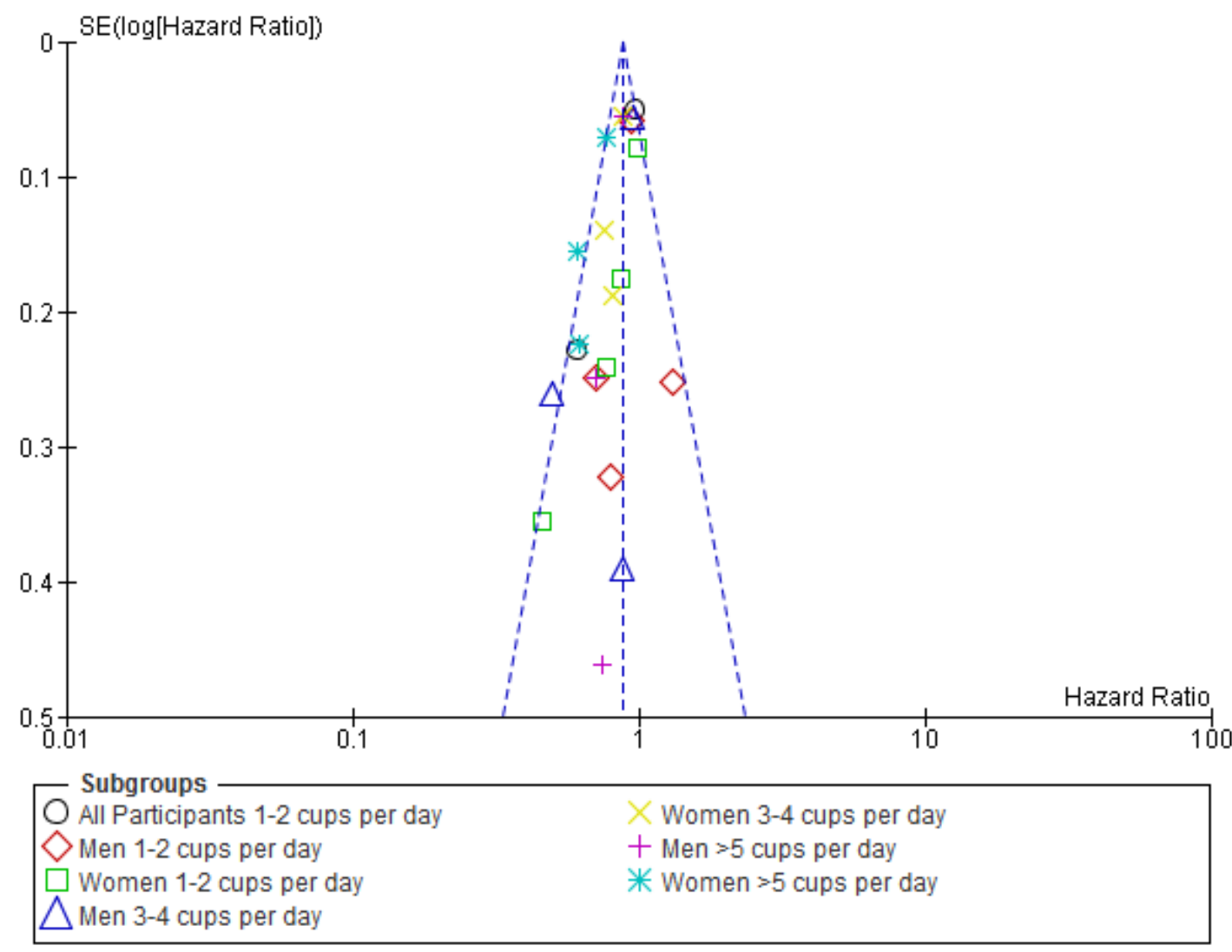

Figure 3. Funnel Plot

\section{DISCUSSION}

The following possible hypotheses may explain these results: suppression of cholesterol biosynthesis (Cuccioloni et al., 2011); increase in fecal excretion of cholesterol because of green tea polyphenol, (-)-epigallocatechin-3-gallate treatment which could reduced body weight, decreased liver weight, liver triglycerides, plasma alanine amino transferase concentrations, decreased mesenteric fat weight and blood glucose (Bose et al., 2008); and interference of lipid absorption which green tea polyphenol, (-)epigallocatechin-3-gallate treatment could decreased lipid absorption and reduced levels of inflammatory cytokines (Chen et al., 2011).

Additionally, polyphenols in tea have antioxidative properties that prevent the oxidation of LDL in vitro or vivo also flavonoids may protect LDL against oxidation in atherosclerotic lesions and may therefore be natural anti-atherosclerotic components of the diet (Whalley et al., 1990) and contribute to the concentrations of auto antibodies against oxidized LDL in patients with atherosclerosis (Salonen et al., 1992; Zhang et al., 2015).

Moreover, the occurrence and synthesis of nitric oxide (endothelial dysfunction, a prognostically relevant key event in atherosclerosis, is characterized by a decreased of this colorless gas), the primary modulator of vascular dilation, were found to be prolonged and augment, respectively, by polyphenols, particularly (-)-epicatechin (Schroeter et al., 2006), through two possible ways: 1) activation of endothelial nitric oxide synthase enzymes, which then regulate nitric oxide production from L-arginine (Rezende et al., 2016; Schroeter et al., 20o6); and 2) modulation of xanthine oxidase 
activity, decreasing oxidative injury and consequently increasing (Cos et al., 1998).

This is not the first meta-analysis that discuss the effect of green tea consumption on cardiovascular disease related mortality. However this study was differ because some of the original ariticle used was different and the form of analysis of subgroup which based on gender and amount of cups of green tea consumed per day.

The conclusion of this study was consumption of green tea more than one cups per day may reduce the risk of cardiovascular disease related mortality.

There are several limitations in this study. First, this study was limited to only English language articles, and the researchers were not aware of any unpublished articles that fulfilled this study's criteria. Second, there is a limited number of studies that discuss the effect of green tea consumption on cardiovascular disease related mortality, so further study is needed for more evidence. Third, performed subgroup analysis was limited to only two characteristics, whereas more characteristics can be explored, such as settings, smo-king status, duration of green tea consumption.

\section{ACKNOWLEDGEMENT}

The author relay gratitude to the online database providers of PubMed, ResearchGate, Science Direct, Google Scholar and EBSCO.

\section{FINANCIAL AND SPONSORSHIP}

This review funded author personal fund.

\section{CONFLICT OF INTEREST}

The author declares there is no conflict of interest in this study.

\section{REFERENCES}

Balentine DA, Wiseman SA, Bouwens LC (1997). The chemistry of tea flavonoids. Crit Rev Food Sci Nutr. 37(8): b693-704. doi: 10.1080/10408399709527797.

Bose M, Lambert JD, Ju J, Reuhl KR, Shapses SA, Yang CS (2018). The major green tea polyphenol, (-)-epigallocatechin-3-gallate, inhibits obesity, metabolic syndrome, and fatty liver disease in high-fat-fed mice. J Nutr. 138(9): 1677-1683. doi: 10.1093/jn/138.9.1677.

Brown MS, Goldstein JL (1998). Sterol regulatory element binding proteins (SREBPs): controllers of lipid synthesis and cellular uptake. Nutr Rev. 56 (2 Pt 2): S1-S3; discussion S54-S75. doi: 10.1111/j.1753-4887.1998.tbo1680.x.

Chen D, Milacic V, Chen MS, Wan SB, Lam WH, Huo C, Landis-Piwowar KR, et al., (2008). Tea polyphenols, their biological effects and potential molecular targets. Histol Histopathol. 23(4): 487-496. doi: 10.14670/HH23.487 .

Chen Y-K, Cheung C, Reuhl KR, Liu AB, Lee M-J, Lu Y-P, Yang CS (2011). Effects of green tea polyphenol (-)epigallocatechin-3-gallate on newly developed high-fat/ Western-style diet-induced obesity and metabolic syndrome in mice. J Agric Food Chem. 59(21): 11862-11871. doi: 10.1021/jf2029016.

Cos $\mathrm{P}$, Ying $\mathrm{L}$, Calomme $\mathrm{M}$, $\mathrm{Hu} \mathrm{JP}$, Cimanga K, Poel BV, Pieters L, et al. (1998) Structure-activity relationship and classification of flavonoids as inhibitors of xanthine oxidase and superoxide scavengers. J Nat Prod. 61(1): 71-76. doi:10.1021/np970237h.

Cuccioloni M, Mozzicafreddo M, Spina M, Tran CN, Falconi M, Eleuteri AM, Angeletti M (2011). Epigallocatechin3-gallate potently inhibits the in vitro activity of hydroxy-3-methyl-glutaryl- 
Nurhayati et al./ Green Tea Consumption with Cardiovascular Related Mortality

CoA reductase. J Lipid Res. 52(5):

897-907. doi:10.1194/jlr.Mo11817.

Erba D, Riso P, Bordoni A, Foti P, Biagi PL, Testolin G (2005). Effectiveness of moderate green tea consumption on antioxidative status and plasma lipid profile in humans. J Nutr Biochem. 16(3): 144-149. doi: 10.1016/j.jnutbio.2004.11.006.

Imai K, Nakachi K (1995). Cross sectional study of effects of drinking green tea on cardiovascular and liver diseases. BMJ. 310(6981): 693-696. doi: 10.1136/bmj.310.6981.693.

Katiyar SK, Elmets CA (2001). Green tea polyphenolic antioxidants and skin photoprotection (Review). Int J Oncol. 18(6): 1307-1313. doi: 10.3892/ijo.18.6.1307.

Khan N, Mukhtar H (2018). Tea Polyphenols in Promotion of Human Health. Nutrients. 11(1). doi: 10.3390/nu11010039.

Kuhn DJ, Burns AC, Kazi A, Dou QP (2004). Direct inhibition of the ubiquitin-proteasome pathway by ester bond-containing green tea polyphenols is associated with increased expression of sterol regulatory elementbinding protein 2 and LDL receptor. Biochim Biophys Acta. 1682(1-3): 110. doi: 10.1016/j.bbalip.2003.12.006.

Liu J, Liu S, Zhou H, Hanson T, Yang L, Chen Z, Zhou M (2016). Association of Green Tea Consumption with Mortality from All-cause, Cardiovascular Disease and Cancer in a Chinese cohort of men. Eur J Epidemiol. 31(9): 853-865. doi: 10.1007/s10654-016-0173-3.

Maron DJ, Lu GP, Cai NS, Wu ZG, Li YH, Chen H, Zhu JQ, et al. (2003). Cholesterol-lowering effect of a theaflavin-enriched green tea extract: a ran- domized controlled trial. Arch Intern Med. 163(12): 1448-1453. doi: 10.1001/archinte.163.12.1448.

Miller PE, Zhao D, Frazier-Wood AC, Michos ED, Averill M, Sandfort V, Burke GL, et al., (2017). Associations of Coffee, Tea, and Caffeine Intake with Coronary Artery Calcification and Cardiovascular Events. Am J Med. 130(2): 188-197.e5. doi: 10.1016/j.amjmed.2016.08.038.

Nagao T, Hase T, Tokimitsu I (2007). A green tea extract high in catechins reduces body fat and cardiovascular risks in humans. Obesity (Silver Spring). 15(6): 1473-1483. doi: 10.1038/oby.2007.176.

Nagaya N, Yamamoto H, Uematsu M, Itoh T, Nakagawa K, Miyazawa T, Kangawa K, et al. (2004). Green tea reverses endothelial dysfunction in healthy smokers. Heart. 90(12): 14851486. doi:10.1136/hrt.2003.026740.

Putri SI, Widiyanto A, Fajriah AS, Atmojo JT, Akbar PS, Qomariah NL (2021). Health Education for the Prevention of COVID-19 Transmission with the 3M Movement in Ngaglik District, Batu City, East Java. Jurnal Empathy Pengabdian Kepada Masyarakat, 5762.

Rezende BA, Pereira AC, Cortes SF, Lemos VS (2016). Vascular effects of flavonoids. Curr Med Chem. 23(1): 87102. doi: 10.2174/0929867323666151111143616.

Salonen JT, Ylä-Herttuala S, Yamamoto R, Butler S, Korpela H, Salonen R, Nyyssönen K, et al. (1992). Autoantibody against oxidised LDL and progression of carotid atherosclerosis. Lancet. 339 (8798): 883-887. doi: 10.1016/0140-6736(92)90926-t.

Samavat H, Newman AR, Wang R, Yuan JM, Wu AH, Kurzer MS (2016). Effects 
Nurhayati et al./ Green Tea Consumption with Cardiovascular Related Mortality

of green tea catechin extract on serum lipids in postmenopausal women: a randomized, placebo-controlled clinical trial. Am J Clin Nutr. 104(6): 1671-1682. doi:10.3945/ajcn.116.137075 .

Schroeter H, Heiss C, Balzer J, Kleinbongards P, Keen CL, Hollenberg NK, Sies H, et al. (2006). (-)-Epicatechin mediates beneficial effects of flavanol-rich cocoa on vascular function in humans. Proc Natl Acad Sci USA. 103(4): 1024-1029. doi: 10.1073/pnas.0510168103.

Serafini M, Ghiselli A, Ferro-Luzzi A (1996). In vivo antioxidant effect of green and black tea in man. Eur $\mathrm{J}$ Clin Nutr. 50(1): 28-32.

Tong X, Taylor AW, Giles L, Wittert GA, Shi $Z$ (2014). Tea consumption is inversely related to 5 -year blood pressure change among adults in Jiangsu, China: a cross-sectional study. Nutr J. 13: 98. doi:10.1186/1475-2891-1398.

Vinson JA, Teufel K, Wu N (2004). Green and black teas inhibit atherosclerosis by lipid, antioxidant, and fibrinolytic mechanisms. J Agric Food Chem. 52(11): 3661-3665. doi: 10.1021/jfo35255 l.

Wang ZM, Zhou B, Wang YS, Gong QY, Wang QM, Yang JJ, Gao W, et al., (2011). Black and green tea consumption and the risk of coronary artery disease: a meta-analysis. Am J Clin Nutr. 93(3): 506-515. doi: 10.3945/ajcn.110.005363.

Whalley CVD, Rankin SM, Hoult JR, Jessup W, Leake DS (1990). Flavonoids inhibit the oxidative modification of low-density lipoproteins by macrophages. Biochem Pharmacol. 39(11): 1743-1750. doi: 10.1016/00o6-2952(90)90120-a.
Widiyanto A (2017). Hubungan Kepatuhan Minum Obat dengan Kesembuhan Pasien Tuberkulosis Paru BTA Positif di Puskesmas Delanggu Kabupaten Klaten. Interest: Jurnal Ilmu Kesehatan, 6(1), 7-12.

Widiyanto A, Atmojo JT, Darmayanti AT (2019). Pengaruh faktor kerawanan pangan dan lingkungan terhadap stunting. Interest: Jurnal Ilmu Kesehatan. 8(1): 61-66.

Widiyanto A, Handayani RT, Atmojo JT (2020). Issues, Challenges, and Potential of Palliative Care in Pediatric Nursing: A Systematic Review. Journal of Maternal and Child Health. 5(1): 167-172.

Widiyanto A, Handayani RT, Mahrifatulhijah M, Atmojo JT, Darmayanti AT (2019). The Canadian Emergency Department Triage \& Acuity Scale (CTAS) dan Perubahannya: A REVIEW. Avicenna: Journal of Health Research. 2(2): 88-95.

Widiyanto A, Murti B, Soemanto RB (2018). Multilevel analysis on the Socio-Cultural, lifestyle factors, and school environment on the risk of overweight in adolescents, Karanganyar district, central Java. J Epidemiol Public Health. 3(1): 94-104.

Yang YC, Lu FH, Wu JS, Wu CH, Chang CJ (2004). The protective effect of habitual tea consumption on hypertension. Arch Intern Med. 164(14): 1534-1540. doi: 10.1001/archinte.164.14.153. 